\title{
CAPITAL STRUCTURE AND FIRM PERFORMANCE: AN APPLICATION ON MANUFACTURING INDUSTRY
}

\author{
Emin AVCI ${ }^{*}$
}

\begin{abstract}
Capital structure and its possible effects on the firms' financial and real decisions have been one of the most debated concepts in finance literature. This paper investigates the relation between firms' financial and real decisions, in terms of capital structure and firm performance. Such possible relation is analyzed for the manufacturing firms, which are traded in Borsa Istanbul during the period of 20032015. Return on equity and return on assets are used as measures of firm performance; and short-term debt to total assets, long-term debt to total assets and debt to equity is used as explanatory variables; the total assets are control variables.

The findings of the study presented that for both short-term debt and long-term debt have a negative and statistically significant effect on both return
\end{abstract}

Keywords: Capital structure, Firm performance, Return on equity, Return on asset

JEL Classification: C33, G32

\section{SERMAYE YAPISI VE FİRMA PERFORMANSI: IMMALAT SANAYİ ÜZERİNE BİR UYGULAMA}

\section{Özet}

Sermaye yapısı ve sermaye yapısının firmaların finansal ve reel kararları üzerindeki olası etkileri finans yazınında en çok tartışılan konulardan bir tanesidir. Bu çalışma, firmaların finansal ve reel kararları arasındaki ilişkiyi sermaye yapısı ve firma performansı bağlamında incelemektedir. Bu kararlar arasındaki olası ilişki 2003-2015 döneminde Borsa İstanbul'da işlem gören imalat sanayi şirketleri kapsamında incelenmiştir. Öz kaynak karlılığı ve aktif karlılık oranları firma performansı göstergeleri; kısa vadeli borçların toplam varlıklara oranı, uzun vadeli borçların toplam varlıklara oranı ve borç öz kaynak oranları açıklayıcı değişken; toplam varlıklar ise kontrol değişkeni olarak kullanılmıştır.

\footnotetext{
* Assoc. Prof., Marmara University, Faculty of Business Administration, Department of Business Administration,
} eavci@marmara.edu.tr 
Çalışmanın bulguları kısa vadeli borçların ve uzun vadeli borçların firmaların öz kaynak karlılığı ve aktif karlılıklarına negatif ve istatistiki olarak anlamlı etkileri olduğunu göstermiştir.

Anahtar kelimeler: Sermaye yapısı, Firma performansı, Öz kaynak karlılığı, Aktif karlılık

JEL Sınıflaması: C33, G32

\section{Introduction}

Capital structure and its possible effects on firm level activities have been widely discussed in finance literature since 1950s. While one side of the discussion is mainly concentrated on determination of the level optimal capital structure and the determinants of capital structure, on the other side effects of capital structure on firm values and firm performance are another discussion points.

One of the clear explanation of the capital structure and its effects on firm level decision was given by Stiglitz ${ }^{1}$, who stated that the firm level decisions could be classified under 4 headings: (1) financing of investments, (2) profit distribution, (3) amount of investment, and (4) selection of investment projects. Stiglitz ${ }^{2}$ mentioned that the first two decisions can be regarded as financial decisions, and the remaining are the real decisions. From this point of view, the discussions about the capital structure is about explaining the interactions between the financial and real decisions of the firm. On the other hand, if the Modigliani and Miller's ${ }^{3}$ propositions are accepted than there should be no interactions between financial and real decisions of firms.

In this study, by utilizing the data of industrial companies, which are traded in Borsa Istanbul, the effect of capital structure on the firm performances, in another saying the interactions between financial and real decision of firms, will be analyzed. Panel data analysis is used for a period of 2003-2015 for analysis of the companies, which do not have any missing data during the period of analysis. The second section of the study is the related literature, third section is the methodology, forth section is the empirical findings and the last section is the conclusion.

\section{Theoretical Background and Literature Review}

There is a vast amount of studies, which are analyzing the determinants of capital structure, optimum capital structure and effects of capital structure decision on different aspects of firm. A

1 Joseph E. Stiglitz, “On the irrelevance of corporate financial policy”, The American Economic Review, 64(6), 1974, pp. 851-866.

2 Stiglitz, Ibid., p. 851.

3 Franco Modigliani and Merton H. Miller, "The Cost of Capital, Corporation Finance and the Theory of Investment", The American Economic Review, 48(3), 1958, pp. 261-297. 
brief theoretical background and the literature on the empirical findings will be given under this section.

\section{I. Theoretical Background}

The theoretical origins of the capital structure studies dated back to the seminal article of Modigliani and Miller ${ }^{4}$, which basically presented the relation between cost of capital and firm value. Although the aim of this study is not provide capital structure theories in detail, basic explanation will be given below.

Modigliani and Miller ${ }^{5}$ proposed that the value of a firm is independent from its capital structure (debt to equity) under the assumptions of no taxes, no transaction costs, no bankruptcy costs, symmetric information and perfect markets. Such proposition is also called as the Irrelevance Theory of capital structure. The underpinnings of the proposition lies in the availability of the arbitrage opportunity that offset any effect of the leverage by creating homemade leverage. Following their original propositions, Modigliani and Miller ${ }^{6}$ made a correction about the relation between capital structure and firm value with taxes. The existence of taxes create a tax shield, as interest payments on debt can be deductible from taxes, thus the value of a firm is subject to increase by altering leverage; such that in extreme case, a firm can be financed $100 \%$ debt $^{7}$.

Although, there are strict assumptions of the Modigliani and Miller's propositions about capital structure, they pioneered many other study in the finance literature. Several studies argued that although there are benefits of debt financing it also possess some cost. Such that firms have to determine their capital structure by balancing the costs and benefits of leverage, and there should be an optimal capital structure. Such balancing behavior for capital structure is examined under the Trade-off Hypothesis of capital structure.

The trade of hypothesis states that the benefits of debt are the advantage tax shield and limitation of the free cash flow problem; whereas the disadvantages are mainly the bankruptcy costs and agency problems ${ }^{8}$. The main issues in trade-off theory in determining the optimal capital structure is the significance of debt related costs and its effects on the cost of borrowing ${ }^{9}$. However, with the extensions to the theory, it shown that the corporate tax advantage can be limited with personnel

4 Modigliani and Miller, The Cost of Capital...Ibid., pp.261-297.

5 Modigliani and Miller, Ibid.

6 Franco Modigliani and Merton H. Miller, "Corporate Income Taxes and the Cost of Capital: A Correction", The American Economic Review, 53(3), 1963, pp. 433-443.

7 James L. Berens and Charles J. Cuny, “The capital structure puzzle revisited”, The Review of Financial Studies, 8(4), 1995, pp. 1185-1208.

8 Eugene F. Fama and Kenneth R. French, “Testing trade-off and pecking order predictions about dividends and debt”, The Review of Financial Studies, 15(1), 2002, p.5.

9 Michael Bradley, Gregg A. Jarrel and E. Han Kim, "On the existence of an optimal capital structure: theory and evidence”, The Journal of Finance, 39(3), 1984, p. 857. 
taxes ${ }^{10}$, and moreover Miller ${ }^{11}$ presented that the tax advantage of debt can be offset by the effects of personnel taxes.

Following the extension to trade off theory, the information asymmetries and its possible effects on capital structure attracted researchers' interest. The origins of the asymmetric information is the reality that investors are less informed than the insiders, thus the value of equity can be mispriced $^{12}$. In a similar manner, although both equity and debt have adverse selection problem, equity face a higher adverse selection, thus outside investors demand higher returns for equity ${ }^{13}$. In such cases, if new equity is used as a financial source for new investments, cost of mispricing will be cost to the existing shareholders and cause an underinvestment problem. Thus, other than new equity issues, internal funds and riskless debt should be at the first place.

Such preference, in the order of internal funds, debt and equity in the existence of asymmetric information borne a new theory of capital structure, which is called Pecking Order Theory. The origins of the theory is based on the studies of Myers ${ }^{14}$ and Myers and Majluf ${ }^{15}$.

Another main branch of capital structure theories based on the agency cost of debt and equity. Jensen and Meckling ${ }^{16}$ argued that at low levels of leverage, increase in debt can reduce total agency cost. However, beyond some point, as result of liquidation and bankruptcy costs, agency cost of debt is subject to increase. Moreover, Jensen ${ }^{17}$ stated that leverage can be used as tool for reducing the management waste of funds and increase their performance to generate cash for debt servicing, such effect of debt is also called Free Cash Flow Theory. In a similar manner, Grossman and $\mathrm{Hart}^{18}$ argued that debt can induce management to increase their performance as possible bankruptcy will have costs to management like losing position.

When above theories are evaluated as a whole the relation between capital structures and firm performance is subject to change according to different aspects of each theory. From the theoretical perspective the leverage should be higher because of tax advantage, so that profitable firms should borrow more to take the advantage of tax shield. In a similar way, because of the control effect of the debt, there should be a positive relation between leverage and profitably. On

10 Stewart C. Myers, S.C., "Determinants of corporate borrowing”, Journal of Financial Economics, 5, 1977, pp. 147175.

11 Merton H. Miller, “Debt and Taxes”, The Journal of Finance, 32(2), 1977, pp. 261-275.

12 Milton Harris and Artur Raviv, “The theory of capital structure”, The Journal of Finance, 46(1), 1991 , p. 306.

13 Murray Z. Frank and Vidhan K. Goyal, “Testing the pecking order theory of capital structure”, Journal of Financial Economics, 67, 2003, p. 220.

Stewart C. Myers, “The capital structure puzzle”, Journal of Finance, 39, 1984, pp. 575-592.

Stewart C. Myers and Majluf, N., "Corporate financing and investment decisions when firms have information that investors do not have”, Journal of Financial Economics, 13, 1984, pp. 187-221

Micheal H. Jensen and William Meckling, "Theory of the firm: Managerial behavior, agency costs, and capital Structure", Journal of Financial Economics, 3, 1976, pp.305-360.

17 Micheal C. Jensen, "Agency costs of free cash flow, corporate finance and takeovers", American Economic Review, 76, 1986, pp. 323-339.

18 Stanford J. Grossman and Oliver D. Hart, "Corporate financial structure and managerial incentives", In “The Economics of Information and Uncertainty”, McCall, J.J. (ed.), NBER,1982, pp.107-140. 
the other hand, as profitable firms are able to generate funds from internal sources, leverage and profitability should be negatively related. Moreover, increase in leverage raises some costs such as bankruptcy cost and agency costs.

\subsection{Literature Review}

The studies about capital structure and its possible effect on the firms are enormous and present conflicting results. Among these studies, the researches that have empirically investigated or reported the relation between capital structures with firm performances will be summarized in this part. The international evidences will be given as a first place and a special emphasis will be placed for the evidences from Turkish firms.

Several studies tried to find out an empirical evidence about the capital structure and firm performance relation from cross country perspective. Most of which reported a negative relation between capital structure and firm performance. Among these studies, Rajan and Zingales ${ }^{19}$ analyzed 31 countries and documented a negative correlation between profitability and leverage and stated that the increases in size should foster such negative relation. Gleason, et al., ${ }^{20}$ showed that the cultural differences effects the capital structure for 14 European countries. Results of their study presented a negative relation between leverage and firm performance. Booth, et al., ${ }^{21}$ tried figure out the possible differences in developed and developing countries in terms of capital structure by studying 10 developing countries. In line with the pecking order hypothesis but contrary to trade of theory, the results showed that the higher is the profitability the lower is the leverage. Moreover, they concluded that the findings showed the existence of information asymmetries. Goddard, et al., ${ }^{22}$ analyzed the factors effecting firm profitability in 5 European countries. While a negative relation between firm profitability and gearing ratio, there is a positive relation between profitability and liquidity. González ${ }^{23}$ studied the relation between leverage and firm performance among 39 countries. The results of the study presented that performance and leverage are negatively related, hence concluded that the cost of financial distress is more than the benefits of control effect of debt.

Besides in the international cross country evidences some other studies concentrated on one country. Among these, several studies analyze the USA firms. Taub ${ }^{24}$ found that if the difference

19 Raghuram G. Rajan and Luigi Zingales, "What do we know about capital structure? Some evidence from international data”, The Journal of Finance, 50(5), 1995, pp. 1421-1460.

20 Kimberly C. Gleason, Lynette K. Mathur and Ike Mathur, “The interrelationship between culture, capital structure, and performance: Evidence from European retailers”, Journal of Business Research, 50, 2000, pp. 185-191.

21 Laurence Booth, L., Varouj Aivazian, Asli Demirguc-Kunt and Vajislav Maksimovic, "Capital structures in developing countries", The Journal of Finance, 56(1), 2001, pp. 87-130.

22 John Goddard, Manounche Tavakoli and John O.S. Wilson, "Determinants of profitability in European manufacturing and services: evidence from a dynamic panel model”, Applied Financial Economics, 15, 2005, pp. 1269-1282.

23 Victor M. Gonzales, "Leverage and corporate performance: international evidence", International Review of Economics and Finance, 25, 2013, pp. 169-184.

24 Allan J. Taub, "Determinants of the Firm's Capital Structure”, The Review of Economics and Statistics, 57(4), 1975, pp. 410-416. 
between return to firm and cost of long term debt is high, the possibility of new debt issue increase. Hence, there is a positive relation between debt-to-equity ratio with difference in return and long-term debt interest. Moreover, there is a negative relation between uncertainties of future earnings with leverage. Titman and Wessels ${ }^{25}$ found that a negative relation between profitability with debt levels when the relation is investigated with market value of equity. Opler and Titman ${ }^{26}$ analyzed relation between leverage and firm performance in distressed industries. The results of the study showed a positive relation between financial condition and performance, where high leverage firms have low operating profits and lose market share in distressed industries. Fama and French ${ }^{27}$ reported that profitable firms have less leverage, which is calculated for both of book and market values. Berger and Patti ${ }^{28}$ analyzed the validity of the agency cost theory in commercial banking sector using profit efficiency measure. The findings of the study presented a significant and positive relation between the leverage and the profit efficiency.

Asgharian $^{29}$ studied the relation between leverage and profitability in distressed industries, which is the industries with negative median growth in sales, in Sweden. The findings presented that in a distressed industry, firms with high leverage have a lower growth in sales but higher growth in profitability. On the other hand, a negative relation between stock returns and leverage is documented regardless of the industry type. Tong and Green ${ }^{30}$ studied the Chinese listed companies and found, in line with pecking order theory, a significant negative correlation between profitability and leverage. Margaritis and Psillaki ${ }^{31}$ investigated the effect of efficiency on capital structure in New Zealand firms. In line with agency cost hypothesis, they found leverage and efficiency are positively related. Also, they report a positive relation between profitability and leverage. Ebaid ${ }^{32}$ presented that for Egyptian listed companies capital structure has a negative impact on ROA but no significant relation could be found on other performance measures. Salim and Yadev $^{33}$ studied the relation between capital structure and firm performance in Malaysian companies. The result showed a negative relation between return on assets, return on equity, earning per share with short term debt, long term debt, total debt. On the other hand, Tobin's

25 Sheridan Titman and Roberto Wessels, “The determinants of capital structure”, The Journal of Finance, 43(1), 1988, pp. 1-19.

26 Tim C. Opler and Sheridan Titman, "Financial distress and corporate performance", The Journal of Finance, 49(3), 1994, pp. 1015-1040.

27 Fama and French, ibid., pp. 1-33.

28 Allen N. Berger and Emillia B. Patti, "Capital structure and firm performance: A new approach to testing agency theory and an application to the banking industry", Journal of Banking \& Finance, 30, 2006, pp. 1065-1102.

29 Hossein Asgharian, "Are highly leveraged firms more sensitive to an economic downturn?", The European Journal of Finance, 9(3), 2003, pp. 219-241.

30 Guanqun Tong and Christopher J. Green, "Pecking order or trade-off hypothesis? Evidence on the capital structure of Chinese companies”, Applied Economics, 37, 2005, pp. 2179-2189.

31 Dimitris Margaritis and Maria Psillaki, "Capital structure and firm efficiency", Journal of Business Finance \& Accounting, 34(9-10), 2007, pp.1447-1469.

32 İbrahim E.S. Ebaid, "The impact of capital-structure choice on firm performance: empirical evidence from Egypt", The Journal of Risk Finance, 10(5), 2009, pp. 477 - 487.

33 Mahfuzah Salim and Raj Yadav, "Capital structure and firm performance: evidence from Malaysian listed companies", Procedia - Social and Behavioral Sciences, 65, 2012, pp. 156 - 166. 
Q has a positive relation with short term debt and long term debt, however, there is a negative relation with total debt. Sheihk and Wang ${ }^{34}$ examined the effect of leverage on performance in non-financial Pakistani firms. The findings of the study presented a negative relation between total debt, short-term and long-term debt with return on assets. However, for the relation between market-to-book value with capital structure is subject to change under different statistical methods. Dawar ${ }^{35}$ found a negative relation between firm performance (in terms of ROA and ROE) with short-term and long-term debt ratios for Indian companies. On the other hand, Chadra and Sharma ${ }^{36}$ studied Indian manufacturing firms and results of the study presented that there no significant relation between leverage and ROA and Tobin's Q; however, there is a significant negative relation between leverage and ROE. Tsuruta ${ }^{37}$ reported that for Japanese SME's high leverage firms perform better than low leverage firms in terms of sales growth. Moreover, when SMEs' have profitable investment opportunities than they tend to have less increase in short-term debt and trade payables. Vithessonthia and Tonguraib ${ }^{38}$ investigated the effects of firm size on the relation between performance and leverage with Thailand sample. The analysis with whole sample data showed a positive effect of leverage on firm performance; however, when size is considered, leverage has a negative effect on performance for large firms and positive effect for small ones. In another study, Vithessonthia and Tonguraib ${ }^{39}$ investigated the effect of internationalization on the relation between leverage and firm performance and found that the leverage has an higher effect on performance for international firms than domestic ones. Moreover, leverage has a negative effect for domestic and positive effect for international firms. Islam and Khandaker ${ }^{40}$, by proposing the existence of the capital structure differences could be result of sectoral differences, analyzed the capital structure in Australian mining and non-mining companies. The results presented that there is a negative relation between leverage and profitability in mining companies but a positive relation in non-mining companies.

There are also several studies related with the capital structure and its possible effects on Turkish firms. Among these, some studies concentrated on the relation between market value and financial ratios. Ayrıçay and Türk ${ }^{41}$ presented that market value is a positively related with

34 Nadeem A. Sheikh and Zongjun Wang, "The impact of capital structure on performance", International Journal of Commerce and Management, 23(4), 2013, pp. $354-368$.

35 Varun Dawar, "Agency theory, capital structure and firm performance: Some Indian evidence", Managerial Finance, 40(12), 2014, pp. 1190 - 1206

36 Sauraph Chadha and Anil K. Sharma, "Capital structure and firm performance: Empirical evidence from India", The Journal of Business Perspective, 19(4), 2015, pp. 295-302.

37 Daisuke Tsuruta, "Leverage and firm performance of small businesses: evidence from Japan", Small Business Economics, 44, 2015, pp. 385-410.

38 Chaiporn Vithessonthia and Jittima Tonguraib, "The effect of firm size on the leverage-performance relationship during the financial crisis of 2007-2009”, Journal of Multinational Financial Management, 29, 2015a, pp. 1-29.

39 Chaiporn Vithessonthia and Jittima Tonguraib, "The effect of leverage on performance: Domestically-oriented versus internationally-oriented firms", Research in International Business and Finance, 34, 2015b, pp. 265-280.

40 Silva Z. Islam and Sarod Khandaker, "Firm leverage decisions: does industry matter?", North American Journal of Economics and Finance, 31, 2015, pp. 94-107.

41 Yücel Ayrıçay and Veysel E. Türk, "Finansal oranlar ve firma değeri ilişkisi: BİST’de bir uygulama", Muhasebe ve Finansman Dergisi, Ekim 2014, pp. 53-70 
liquidity ratio but negatively related with financial leverage. In a similar study, Birgili and Düzer ${ }^{42}$ find a negative relation between leverage and firm value.

Some other studies analyzed the relation between stock returns and financial ratios. While Büyükşalvarci ${ }^{43}$ reported existence of a nonlinear relation between leverage ratios and stock return; Kalayc1 and Karataşs ${ }^{44}$ found no relation in leverage and stock returns.

On the other hand, some other studies are mostly concentrated on the determinants or the factors effecting the capital structure decisions. Durukan ${ }^{45}$ found that profitability and non-debt tax shield as the most important factors effecting the capital structure; and there exist a negative relation between debt ratios and profitability. Okuyan and Taşc ${ }^{46}$ analyzed the determinants of capital structure in industrial firms. The findings of the study presented that the size and profitability results a lower debt levels, which supports the pecking order theory. On the other hand, Şahin ${ }^{47}$ studied the determinants of capital structure for small and medium sized enterprises, which are traded in Borsa Istanbul. In line with pecking order theory, findings pointed out negative relation between RAO, total debt and short-term debt; and a negative relation between ROE and long-term debt. Similar results were also presented by Gülşen and Ülkütaş̧, where they found a negative relation between profitability and leverage but a positive relation between leverage, dividends and last year profitability. In a recent study, Kara and Erdur ${ }^{49}$, reported that the relation between capital structure and profitability is subject to change according to sectors. However, they also presented a negative relation, which was not effected from sectoral differences, between asset structure, liquidity and capital structure.

The remaining literature deal with the relation between capital structure and profitability. Among these studies, Topal ${ }^{50}$ analyzed the capital structure of manufacturing firms and pointed out the relation between leverage ratios and firm profitability. The findings of the study presented

42 Erhan Birgili and Murat Düzer, "Finansal analizde kullanılan oranlar ve firma değeri ilişkisi: İMKB'de bir uygulama", Muhasebe ve Finansman Dergisi, 46, 2010, pp. 74-83.

43 Ahmet Büyükşalvarci, "Finansal oranlar ile hisse senedi getirileri arasındaki ilişkinin analizi: İMKB imalat sektörü üzerine bir araştırma", Muhasebe ve Finansman Dergisi, 48, 2010, pp. 130-141. Şeref Kalaycı and Abdülmecit Karataş, "Hisse senedi getirileri ve finansal oranlar ilişkisi: İMKB’de bir temel analiz araştırması”, Muhasebe Finansman Dergisi, 9, 2005, pp. 146-157.

M. Banu Durukan, "Hisse senetleri İMKB’de İșlem gören firmaların sermaye yapısı", İMKB Dergisi, 1(3), 1997, pp. 75-87.

46 H. Aydın Okuyan and H. Mehmet Taşcı, "Sermaye yapısının belirleyicileri:Türkiyedeki en büyük 1000 sanayi işletmesinde bir uygulama”, BDDK Bankacılık ve Finansal Piyasalar Dergisi, 4(1), 2010, pp. 105-120.

47 Osman Şahin, "IMKB’ye kayıtlı kobi şirketlerinde sermaye yapısını belirleyen faktörler ve 2008 yılı finansal krizi, Finans Politik \& Ekonomik Yorumlar, 48(560), 2011, pp. 5-16.

48 Ahmet Z. Gülşen and Özge Ülkütaş "Sermaye yapısının belirlenmesinde finansman hiyerarşisi teorisi ve ödünleşme teorisi: İMKB sanayi endeksinde yer alan firmalar üzerine bir uygulama”, ZKÜ Sosyal Bilimler Dergisi, 8(15), 2012, pp. 49-59.

49 Esen Kara and Duygu A. Erdur, "Determinants of capital structure: a research on sectors that contribute to exports in Turkey", İstanbul Üniversitesi İşletme Fakültesi Dergisi, 44(2), 2015, pp.27-38.

50 Yusuf Topal, “IMKB’ye kayıtlı işletmelerin sermaye yapıları ve finansal kaldıraç oranlarının karlılıklarına etkisi”, Erciyes Üniversitesi İktisadi Ve İdari Bilimler Fakültesi Dergisi, 27, Temmuz-Aralık 2006, pp. 45-70. 
that there is no change in the return on asset and gross profit margin when the leverage is increasing but $\mathrm{P}$ profitability ratio is decreasing. In analyzing the factors effecting profitability of manufacturing and service companies, Albayrak and Akbulut ${ }^{51}$ found a negative relation between capital structure and return on assets but a positive relation between capital structure and return on equity. Thus, they concluded that the cost of debt during the period of analysis was lower than return on assets, which stimulates the return on equity. On the other hand, in a recent study Kisakürek and Aydin ${ }^{52}$ reported, although the finds were subject to change on yearly basis, generally a negative relation between return on equity and capital structure; and a positive relation between return on assets.

\section{Data and Methodology}

The relation between capital structure and firm performance is studied by using on the industrial firms which are traded in Borsa Istanbul during the period of 2003-2015.

For each year in the analyzing period, total of 110 firms are included in the sample set, as some firms have mission variables or are not traded in the Borsa İstanbul for all years under investigation. Hence, there is total of 1,430 observations.

In order to test the possible effects of capital structure on firm performance, several variables were utilized in the literature. As a performance indicator return on assets, return on equity and Tobin's $\mathrm{Q}$ are the most common ones; profit margin, profit efficiency and stock return are also used. As an indicator of capital structure, the leverage ratios are utilized such as debt to equity, short-term debt to total assets, long-term debt to total assets, financial debts. Besides the performance and capital structure measures, most of the studies used control variables such as size, industry, firm age, tangibility, growth in sales.

In this study, relying on the most common variables in the literature, return on assets (ROA) and return on equity (ROE) is used as dependent variables, where debt to equity (D/E), shortterm debt to total assets (STD/TA) and long-term debt to total assets (LTD/TA) are independent variables, hence the logarithm of total assets (for controlling the size) is the control variable.

The list of variables are given in table 1.

51 Ali S. Albayrak and Ramazan Akbulut, "Karlılığı etkileyen faktörler: İMKB sanayi ve hizmet sektörlerinde işlem gören işletmeler üzerine bir inceleme”, ZKÜ Sosyal Bilimler Dergisi, 4(7), 2008, pp. 55-83.

52 M. Mustafa Kısakürek and Yüksel Aydın, "İşletmelerde sermaye yapısı ile kârlılık arasındaki ilişkinin analizi: 1992 2011 yılları arası finansal krizler odaklı BİST’te bir uygulama”, Ç.Ü. İktisadi Ve İdari Bilimler Dergisi, 14(2), 2013, pp. 97-121. 
Table I. List of Variables

\begin{tabular}{lc}
\hline Dependent Variables & Abbreviation \\
\hline Return on Assets & ROA \\
Return on Equity & ROE \\
Independent Variables & \\
Debt to Equity & $\mathrm{D} / \mathrm{E}$ \\
Short-Term Debt to Total Assets & $\mathrm{STD} / \mathrm{TA}$ \\
Long-Term Debt to Total Assets & LTD/TA \\
Control Variable & \\
Total Assets & $\mathrm{TA}$ \\
\hline
\end{tabular}

Using variables defined above, two models were developed for testing the effect of leverage on firm performance. The models are given below:

$$
\begin{aligned}
& R O A=\beta_{0}+\beta_{1}\left(\frac{D}{E}\right)+\beta_{2}\left(\frac{S T D}{T A}\right)+\beta_{3}\left(\frac{L T D}{T A}\right)+\beta_{4} T A+\varepsilon \\
& R O E=\beta_{0}+\beta_{1}\left(\frac{D}{E}\right)+\beta_{2}\left(\frac{S T D}{T A}\right)+\beta_{3}\left(\frac{L T D}{T A}\right)+\beta_{4} T A+\varepsilon
\end{aligned}
$$

In order to analyze the relation between firm performance and capital structure, panel data analysis is utilized and Hausman specification test is conducted.

\section{Empirical Findings}

As stated in previous section, two dependent variables, ROA and ROE; three independent variable, namely debt to equity $(\mathrm{D} / \mathrm{E})$, short-term debt to total assets (STD/TA), long-term debt to total assets (LTD/TA) and one control variable (logarithm of total assets, TA) are utilized in this study. Table 2 represents the summary statistics for the data in use.

Table 2. Summary Statistics

\begin{tabular}{lrrrrrr}
\hline & ROE & \multicolumn{1}{c}{ ROA } & \multicolumn{1}{c}{ D/E } & $\begin{array}{c}\text { STD/ } \\
\text { TA }\end{array}$ & LTD/TA & \multicolumn{2}{c}{ TA } \\
\hline Mean & 6.56 & 5.05 & 0.83 & 31.90 & 12.17 & 8.49 \\
Median & 8.51 & 4.93 & 0.67 & 28.54 & 8.12 & 8.44 \\
Standard Deviation & 0.73 & 0.28 & 0.16 & 0.52 & 0.33 & 0.02 \\
Maximum & 149.01 & 70.37 & 38.45 & 191.93 & 148.44 & 10.41 \\
Minimum & -431.94 & -128.93 & -206.12 & 1.30 & 0.00 & 6.90 \\
Kurtosis & 81.06 & 21.65 & 967.13 & 4.98 & 18.00 & 0.10 \\
Skewness & -6.31 & -1.39 & -28.13 & 1.44 & 3.02 & 0.40 \\
\hline
\end{tabular}


Table 2 presents the mean, median, standard deviation, maximum minimum, kurtosis and skewness of the data set, which composed of 1,430 observation within 2003-2015. The dependent variables ROE and ROA have a mean of 6.56 and 5.05 respectively. The independent variables D/E, STD/TA, and LTD/TA have a mean of $0.83-31.90-12.17$, respectively. The leverage ratios basically present that the industrial firms traded in Borsa İstanbul are mainly financed with equity, as mean of D/E ratio indicating approximately $55 \%$ equity and $45 \%$ debt used on average. When the maturity structure of the debt is analyzed, $31.90 \%$ of total assets are financed with short-term debt and $12.17 \%$ of total assets are financed with long-term debt. Such finding may indicate the preferences of the industrial firm toward short-term debt usage, or most possibly the limited ability of the industrial firms to reach long-term external financial resources.

Table 3. Correlation Matrix

\begin{tabular}{lcccccc}
\hline & ROE & ROA & D/E & STD/TA & LTD/TA & TA \\
\hline ROE & 1.000 & & & & & \\
ROA & 0.678 & 1.000 & & & & \\
D/E & 0.036 & 0.034 & 1.000 & & & \\
STD/TA & -0.277 & -0.488 & -0.001 & 1.000 & & \\
LTD/TA & -0.131 & -0.245 & 0.030 & 0.124 & 1.000 & \\
TA & 0.164 & 0.143 & 0.034 & -0.118 & 0.184 & 1.000 \\
\hline
\end{tabular}

Table 3 presents the correlation matrix of the variables used in the study. Ignoring the correlation between ROE and ROE, which are not used in the same model, the correlation between all variables are less than 0.50 . The highest correlation is observed in between ROA and short-term debt to total assets with -0.488 ; followed by -0.277 correlation between ROE and short-term debt. While the correlation between debt to equity with ROE and ROA is positive; it is negative for both short-term debt and long-term debt. The control variable has a positive correlation with ROE and ROA.

Table 4. Hausman Test for ROE

\begin{tabular}{lcrrl}
\hline & \multicolumn{1}{c}{ Fixed } & \multicolumn{1}{c}{ Random } & Difference & \multicolumn{1}{l}{ S.E. } \\
\hline D/E & 0.0076 & 0.0642 & -0.0566 & 0.0202 \\
STD/TA & -0.4949 & -0.3948 & -0.1000 & 0.0383 \\
LTD/TA & -0.3993 & -0.3248 & -0.0744 & 0.0399 \\
TA & 11.0015 & 7.7935 & 3.2080 & 2.3587 \\
$\chi 2$ & 12.18 & & & \\
Significance & 0.0161 & & & \\
\hline
\end{tabular}


Table 4 presents the results for Hausman specification statistics for ROE model. The results of the statistics showed that fixed effect model should be used as Prob $>$ chi ${ }^{2}$ is lower than 0.05 .

Table 5. Capital Structure and ROE

\begin{tabular}{lcccc}
\hline & Coef. & \multicolumn{1}{l}{ Std. Err. } & \multicolumn{1}{l}{ t } & P>|t $\mid$ \\
\hline D/E & 0.0076 & 0.1107 & 0.07 & 0.945 \\
STD/TA & -0.4949 & 0.0591 & -8.37 & 0.000 \\
LTD/TA & -0.3993 & -0.0761 & -5.25 & 0.000 \\
TA & 11.0015 & 2.8977 & 3.80 & 0.000 \\
Const. & -66.2268 & 24.3423 & -2.72 & 0.007 \\
\hline
\end{tabular}

Table 5 summaries results of the fixed effect model panel analysis for ROE model. The debt to equity ratio seem to have a positive effect on the return on equity (ROE) but effect of $\mathrm{D} / \mathrm{E}$ is not significant. On the other hand, both short-term debt and long-term debt have a negative relation with return on equity. Moreover, both of them are statistically significant at $1 \%$ level. The effect of short-term debt on return on equity is -0.49 and it is -0.40 for long-term debt, which is interpreted as any increase in both debt ratios will harm the financial performance in term of return on equity. The control variable total assets (TA), which is indicating effect of size, is also have positive relation with return on equity and such relation is statistically significant.

Table 6. Hausman Test for ROA

\begin{tabular}{lcrrl}
\hline & \multicolumn{1}{c}{ Fixed } & \multicolumn{1}{c}{ Random } & Difference & \multicolumn{1}{l}{ S.E. } \\
\hline D/E & 0.0490 & 0.0550 & -0.0060 & 0.0049 \\
STD/TA & -0.2957 & -0.2670 & -0.0286 & 0.0103 \\
LTD/TA & -0.2305 & -0.2060 & -0.2450 & 0.0104 \\
TA & 3.9346 & 2.7599 & 1.1747 & 0.6710 \\
$\chi 2$ & 9.41 & & & \\
Significance & 0.0516 & & & \\
\hline
\end{tabular}

Table 6 presents the results for Huasman specification statistics for ROA model. The results of the statistics showed that random effect model should be used as Prob $>\mathrm{chi}^{2}$ is higher than 0.05. 
Table 7 Capital Structure and ROA

\begin{tabular}{lcrrr}
\hline & Coef. & \multicolumn{1}{c}{ Std. Err. } & \multicolumn{1}{c}{$\mathbf{z}$} & \multicolumn{1}{c}{$\mathbf{P}>|\mathbf{z}|$} \\
\hline D/E & 0.0550 & 0.0346 & 1.59 & 0.112 \\
STD/TA & -0.2670 & 0.0156 & -17.10 & 0.000 \\
LTD/TA & -0.2060 & 0.0216 & -9.50 & 0.000 \\
TA & 2.7599 & 0.6245 & 4.42 & 0.000 \\
Const. & -7.4093 & 5.3182 & -1.39 & 0.164 \\
\hline
\end{tabular}

Table 7 summaries results of the fixed effect model panel analysis for ROA model. The results of ROA model is quite similar to ROE models in terms of direction of the relation between dependent and independent variables and their significance levels. The debt to equity ratio seem to have a positive effect on the return on assets (ROA) but effect of $\mathrm{D} / \mathrm{E}$ is not significant. On the other hand, both short-term debt and long-term debt have a negative effect on return on equity. Moreover, both of them are statistically significant at $1 \%$ level. The effect of short-term debt on return on assets is -0.27 and the effect of long-term debt on return on assets is -0.21 . As in the ROE model, as any increase in both debt ratios will harm the financial performance, which is measured in terms of return on assets. The control variable total assets (TA), which is indicating effect of size, also have positive relation with return on equity and such relation is statistically significant.

\section{Conclusion}

The capital structure and its effects on firm have been one of the most debated topics in finance literature. Although several theories tried to explain such relation, there is no common consensus on the subject.

This study investigates the relation between capital structure and firm performance on manufacturing firms, which are listed in Borsa Istanbul during the period of 2003-2015. The panel data analysis is utilized to discover such relation by using the data of 110 firms, which are continuously traded in stock exchange during the period of investigation. Return on equity and return on assets are used as performance measures and short-term debt to total assets, long-term debt to total assets and debt to equity ratios are the explanatory variables. And the total assets are control variable.

The findings of the study presented that for both short-term debt and long-term debt have a negative and statistically significant effect on both return on equity and return on assets. This indicates that the cost of both short-term debt and long-terms overwhelms the return on equity and assets, thus decreases the firm performance significantly. 


\section{References}

ALBAYRAK, A.S. and Akbulut, R., "Karlılığı etkileyen faktörler: İMKB sanayi ve hizmet sektörlerinde işlem gören işletmeler üzerine bir inceleme”, ZKÜ Sosyal Bilimler Dergisi, 4(7), 2008, pp. 55-83.

ASGHARIAN, H., "Are highly leveraged firms more sensitive to an economic downturn?", The European Journal of Finance, 9(3), 2003, pp. 219-241.

AYRIÇAY, Y. and Türk, V. E., "Finansal oranlar ve firma değeri ilişkisi: BİST'de bir uygulama”, Muhasebe ve Finansman Dergisi, Ekim 2014, pp. 53-70.

BERENS, J.L. and Cuny, C.J., “The capital structure puzzle revisited”, The Review of Financial Studies, 8(4), 1995, pp. 1185-1208.

BERGER, A.N. and Patti, B., "Capital structure and firm performance: A new approach to testing agency theory and an application to the banking industry", Journal of Banking \& Finance, 30, 2006, pp. 1065-1102.

BRADLEY, M., Jarrel, G.A. and Kim, E. H., "On the existence of an optimal capital structure: theory and evidence", The Journal of Finance, 39(3), 1984, pp. 857.

BİRGİLİ, E. and Düzer, M., "Finansal analizde kullanılan oranlar ve firma değeri ilişkisi: İMKB'de bir uygulama", Muhasebe ve Finansman Dergisi, 46, 2010, pp. 74-83.

BOOTH, L., Aivazian, V., Demirguc-Kunt, A. and Maksimovic, V., "Capital structures in developing countries", The Journal of Finance, 56(1), 2001, pp. 87-130.

BÜYÜKŞALVARCI, A., "Finansal oranlar ile hisse senedi getirileri arasındaki ilişkinin analizi: İMKB imalat sektörü üzerine bir araştırma”, Muhasebe ve Finansman Dergisi, 48, 2010, pp. 130-141.

CHADHA, S. and Sharma, A.K., "Capital structure and firm performance: Empirical evidence from India", The Journal of Business Perspective, 19(4), 2015, pp. 295-302.

ÇATAL, M. F., “Küresel finansal krizin BİST’de işlem gören otomotiv sektörünün sermaye yapısı üzerindeki etkileri”, Atatürk Üniversitesi İktisadi ve İdari Bilimler Dergisi, 28(2), 2014, pp. 179-197.

DAWAR, V., "Agency theory, capital structure and firm performance: Some Indian evidence", Managerial Finance, 40(12), 2014, pp. 1190 - 1206.

DURUKAN, M.B., “Hisse senetleri İMKB'de İşlem gören firmaların sermaye yapısı”, İMKB Dergisi, 1(3), 1997, pp. 75-87.

EBAID, I. E., "The impact of capital-structure choice on firm performance: empirical evidence from Egypt", The Journal of Risk Finance, 10(5), 2009, pp. 477 - 487.

FAMA, E. F. and French, K. R., "Testing trade-off and pecking order predictions about dividends and debt”, The Review of Financial Studies, 15(1), 2002, pp. 1-33.

FRANK, M. Z. and Goyal, V.K., “Testing the pecking order theory of capital structure”, Journal of Financial Economics, 67, 2003, pp. 217-248

GLEASON, K.C., Mathur, L.K. and Mathur, I., "The interrelationship between culture, capital structure, and performance: Evidence from European retailers”, Journal of Business Research, 50, 2000, pp. $185-191$.

GODDARD, J.,Tavakoli, M. and Wilson, J.O.S., "Determinants of profitability in European manufacturing and services: evidence from a dynamic panel model", Applied Financial Economics, 15, 2005, pp. $1269-1282$.

GONZÁLEZ, V.M., "Leverage and corporate performance: international evidence”, International Review of Economics and Finance, 25, 2013, pp. 169-184.

GROSSMAN S.J. and Hart, O.D., "Corporate financial structure and managerial incentives", In “The Economics of Information and Uncertainty”, McCall, J.J. (ed.), NBER, 1982, pp. 107-140.

GÜLŞEN, A.Z. and Ülkütaş, Ö., "Sermaye yapısının belirlenmesinde finansman hiyerarşisi teorisi ve ödünleşme teorisi: İMKB sanayi endeksinde yer alan firmalar üzerine bir uygulama”, ZKÜ Sosyal Bilimler Dergisi, 8(15), 2012, pp. 49-59. 
HARRIS, M. and Raviv, A., “The theory of capital structure”, The Journal of Finance, 46(1), 1991, pp. 297 355

ISLAM, S.Z. and Khandaker, S., “Firm leverage decisions: does industry matter?”, North American Journal of Economics and Finance, 31, 2015, pp. 94-107.

JENSEN, M. C., "Agency costs of free cash flow, corporate finance and takeovers", American Economic Review, 76(2), 1986, pp. 323-339.

JENSEN, M. C. and Meckling, W., "Theory of the firm: Managerial behavior, agency costs, and capital Structure", Journal of Financial Economics, 3, 1976, pp.305-360.

KALAYCI, Ş. and Karataş, A., "Hisse senedi getirileri ve finansal oranlar ilişkisi: İMKB’de bir temel analiz araştırması”, Muhasebe Finansman Dergisi, 9, 2005, pp. 146-157.

KARA, E. and Erdur, D.A., "Determinants of capital structure: a research on sectors that contribute to exports in Turkey”, İstanbul Üniversitesi İşletme Fakültesi Dergisi, 44(2), 2015, pp.27-38.

KISAKÜREK, M.M. and Aydın, Y., "İşletmelerde sermaye yapısı ile kârlılık arasındaki ilişkinin analizi: 1992-2011 yılları arası finansal krizler odaklı BİST’te bir uygulama”, Ç.Ü. İktisadi Ve İdari Bilimler Dergisi, 14(2), 2013, pp. 97-121.

MARGARITIS, D. and Psillaki, M., "Capital structure and firm efficiency”, Journal of Business Finance \& Accounting, 34(9-10), 2007, pp.1447-1469.

MILLER, M.H., "Debt and Taxes", The Journal of Finance, 32(2), 1977, pp. 261-275.

MODIGLIANI, F. and Miller, M. H., "The Cost of Capital, Corporation Finance and the Theory of Investment", The American Economic Review, 48(3), 1958, pp. 261-297.

MODIGLIANI, F. and Miller, M. H., "Corporate Income Taxes and the Cost of Capital: A Correction", The American Economic Review, 53(3), 1963, pp. 433-443.

MYERS, S.C., "Determinants of corporate borrowing”, Journal of Financial Economics, 5, 1977, pp. 147175.

MYERS, S.C., “The capital structure puzzle”, Journal of Finance, 39, 1984, 575-592.

MYERS, S.C. and Majluf, N., "Corporate financing and investment decisions when firms have information that investors do not have", Journal of Financial Economics, 13, 1984, pp. 187-221.

OKUYAN, H. A. and Taşcı, H.M., "Sermaye yapısının belirleyicileri:Türkiyedeki en büyük 1000 sanayi işletmesinde bir uygulama”, BDDK Bankacılık ve Finansal Piyasalar Dergisi, 4(1), 2010, pp. 105 120.

OPLER, T.C. and Titman, S., "Financial distress and corporate performance", The Journal of Finance, 49(3), 1994, pp. 1015-1040.

RAJAN, R.G. and Zingales, L., "What do we know about capital structure? Some evidence from international data”, The Journal of Finance, 50(5), 1995, pp. 1421-1460.

SALIM, M., and Yadav, R., "Capital structure and firm performance: evidence from Malaysian listed companies", Procedia - Social and Behavioral Sciences, 65, 2012, pp. 156 - 166.

SHEIKH, N. A. and Wang, Z., "The impact of capital structure on performance”, International Journal of Commerce and Management, 23(4), 2013, pp. $354-368$.

STIGLITZ, J.E., "On the irrelevance of corporate financial policy", The American Economic Review, 64(6), 1974, pp. 851-866.

ŞAHIN, O., "IMKKB'ye kayıtlı kobi şirketlerinde sermaye yapısını belirleyen faktörler ve 2008 yılı finansal krizi, Finans Politik \& Ekonomik Yorumlar, 48(560), 2011, pp. 5-16.

TAUB, A. J., "Determinants of the Firm's Capital Structure", The Review of Economics and Statistics, 57(4), 1975, pp. 410-416.

TITMAN, S. and Wessels, R., “The determinants of capital structure”, The Journal of Finance, 43(1), 1988, pp. 1-19.

TONG, G. and Green, C.J., "Pecking order or trade-off hypothesis? Evidence on the capital structure of 
Chinese companies", Applied Economics, 37, 2005, pp. 2179-2189.

TOPAL, Y., "İMKB’ye kayıtlı işletmelerin sermaye yapıları ve finansal kaldıraç oranlarının karlılıklarına etkisi”, Erciyes Üniversitesi İktisadi Ve İdari Bilimler Fakültesi Dergisi, 27, Temmuz-Aralık 2006, pp. 45-70.

TSURUTA, D., "Leverage and firm performance of small businesses: evidence from Japan", Small Business Economics, 44, 2015, pp. 385-410.

VITHESSONTHIA, C. and Tonguraib, J., "The effect of firm size on the leverage-performance relationship during the financial crisis of 2007-2009”, Journal of Multinational Financial Management, 29, 2015a, pp. 1-29.

VITHESSONTHI, C. and Tongurai, J., "The effect of leverage on performance: Domestically-oriented versus internationally-oriented firms", Research in International Business and Finance, 34, 2015b, pp. 265-280. 